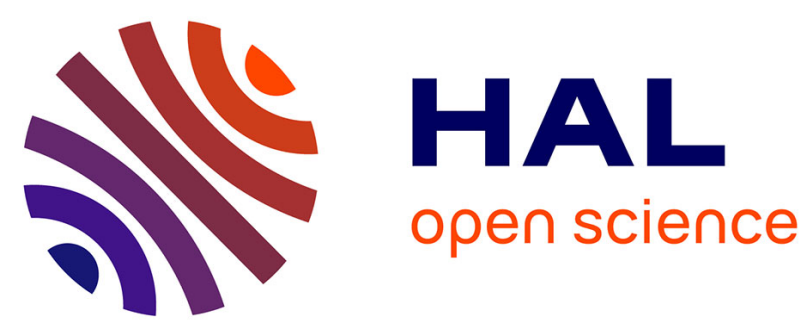

\title{
Determinations of Uranium(VI) Binding Properties with some Metalloproteins (Transferrin, Albumin, Metallothionein and Ferritin) by Fluorescence Quenching
}

\author{
Jérôme Michon, Sandrine Frelon, Cédric Garnier, Frédéric Coppin
}

\section{To cite this version:}

Jérôme Michon, Sandrine Frelon, Cédric Garnier, Frédéric Coppin. Determinations of Uranium(VI) Binding Properties with some Metalloproteins (Transferrin, Albumin, Metallothionein and Ferritin) by Fluorescence Quenching. Journal of Fluorescence, 2010, 20, pp.581-590. 10.1007/s10895-009-0587-3 . hal-01096837

\section{HAL Id: hal-01096837 \\ https://hal-univ-tln.archives-ouvertes.fr/hal-01096837}

Submitted on 5 Jan 2015

HAL is a multi-disciplinary open access archive for the deposit and dissemination of scientific research documents, whether they are published or not. The documents may come from teaching and research institutions in France or abroad, or from public or private research centers.
L'archive ouverte pluridisciplinaire HAL, est destinée au dépôt et à la diffusion de documents scientifiques de niveau recherche, publiés ou non, émanant des établissements d'enseignement et de recherche français ou étrangers, des laboratoires publics ou privés. 


\title{
Determinations of Uranium(VI) Binding Properties with some Metalloproteins (Transferrin, Albumin, Metallothionein and Ferritin) by Fluorescence Quenching
}

\author{
Jérôme Michon • Sandrine Frelon • Cédric Garnier • \\ Frédéric Coppin
}

Received: 16 September 2009 / Accepted: 22 December 2009/Published online: 12 January 2010

(C) Springer Science+Business Media, LLC 2010

\begin{abstract}
The interactions between uranium and four metalloproteins (Apo-HTf, HSA, MT and Apo-EqSF) were investigated using fluorescence quenching measurements. The combined use of a microplate spectrofluorometer and logarithmic additions of uranium into protein solutions allowed us to define the fluorescence quenching over a wide range of $[\mathrm{U}] /[\mathrm{Pi}]$ ratios (from 0.05 to 1150 ) at physiologically relevant conditions of $\mathrm{pH}$. Results showed that fluorescence from the four metalloproteins was quenched by $\mathrm{UO}_{2}{ }^{2+}$. Stoichiometry reactions, fluorescence quenching mechanisms and complexing properties of metalloproteins, i.e. binding constants and binding sites densities, were determined using classic fluorescence quenching methods and curve-fitting software (PROSECE). It was demonstrated that in our test conditions, the metalloprotein complexation by uranium could be simulated by two specific sites $\left(\mathrm{L}_{1}\right.$ and $\left.\mathrm{L}_{2}\right)$. Results showed that the U(VI)-Apo-HTf complexation constant values ( $\left.\log \mathrm{K}_{1}=7.7, \log \mathrm{K}_{2}=4.6\right)$ were slightly higher than those observed for $\mathrm{U}(\mathrm{VI})-\mathrm{HSA}$ complex $\left(\log \mathrm{K}_{1}=6.1\right.$, $\left.\log \mathrm{K}_{2}=4.8\right), \mathrm{U}(\mathrm{VI})-\mathrm{MT}$ complex $\left(\log \mathrm{K}_{1}=6.5, \log \mathrm{K}_{2}=5.6\right)$
\end{abstract}

J. Michon $\cdot$ S. Frelon $\cdot$ F. Coppin $(\bowtie)$

Laboratoire de Radioécologie et Ecotoxicologie,

Institut de Radioprotection et Sûreté Nucléaire,

Cadarache, Bât 186, BP3,

13115 Saint-Paul-lez-Durance Cedex, France

e-mail: frederic.coppin@irsn.fr

\section{Garnier}

Groupe de Physico Toxico Chimie des Systèmes Naturels, Institut des Sciences Moléculaires, (ISM-UMR CNRS 5255),

Université Bordeaux I,

33405 Talence Cedex, France

C. Garnier

Laboratoire PROTEE, Université du Sud Toulon-Var, BP 20132,

83957 La Garde, France and $\mathrm{U}(\mathrm{VI})$-Apo-EqsF complex $\left(\log \mathrm{K}_{1}=5.3, \log \mathrm{K}_{2}=3.9\right)$. PROSECE fitting studies also showed that the complexing capacities of each protein were different: 550 moles of U(VI) are complexed by Apo-EqSF while only 28, 10 and 5 moles of U(VI) are complexed by Apo-HTf, HSA and MT, respectively.

Keywords Metalloproteins · Uranium · Fluorescence quenching $\cdot$ Protein complexing properties $\cdot$ PROSECE

\section{Introduction}

Uranium, an element from the actinides series, is one of the heaviest naturally occurring elements on earth. Its distribution is ubiquitous but its concentration may be increased in some ecosystems due to anthropogenic activities [1]. In aerobic aqueous medium, within the physiological $\mathrm{pH}$ range $(\sim 5$ to $\sim 7.4), \mathrm{U}(\mathrm{VI})$ hydrolyses and is mostly found in the form of hexavalent uranyl ions $\left(\mathrm{UO}_{2}{ }^{2+}\right)$ which is a hard Lewis metal ion. $\mathrm{UO}_{2}{ }^{2+}$ mainly reacts with oxygen ligands in the equatorial plane [2] and the coordination number is 5-6, displaying a bipyramidal geometry with the two oxygen atoms on top [3]. Thus, $\mathrm{UO}_{2}{ }^{2+}$, as the other actinide ions, has the ability to form stable complexes with the many ligands present in biological media. In blood, $\mathrm{UO}_{2}{ }^{2+}$ can bind strongly to plasma proteins and can block the binding of other essential metals $[4,5]$.

Binding studies of uranium compounds with blood components are important in order to understand uranium behaviour in biological tissues. On this line, the present investigation focuses on interactions between $\mathrm{U}(\mathrm{VI})$ and four proteins known to bind metals: human serum apotransferrin (Apo-HTf), human serum albumin (HSA), rabbit 
liver metallothionein (MT) and apo-equine spleen ferritin (Apo-EqSF). Apo-HTf, is a glycoprotein whose normal function is iron transport in blood to sites of uptake for use and storage $[6,7]$. HSA is the most abundant protein in the plasma and among its several physiological roles HSA plays a major role in the transport of ions such as $\mathrm{Cd}^{2+}$, $\mathrm{Cu}^{2+} \mathrm{Ni}^{2+}$ and $\mathrm{Zn}^{2+}$ [8-10]. MT is an ubiquitous protein characterized by its high cysteine content (up to $30 \%$ ) that notably plays a role in homeostasis of the essential trace elements and in heavy metal detoxification [11-13]. ApoEqSF is the iron storage protein capable of storing up to $4500 \mathrm{Fe}(\mathrm{III})$ atoms per molecule that plays an important role in iron homeostasis $[14,15]$. These four metalloproteins are known to bind both some essential and toxic trace metal elements but data describing their behaviour with actinides and particularly uranium are poorly documented. Indeed, only Apo-HTf [3, 16-18] and Apo-EqSF [15] are known to bind $\mathrm{UO}_{2}{ }^{2+}$ but data in literature are sometimes incomplete.

A good characterization of a Metal-Protein system implies the determination of the binding site number, their stoichiometry and the corresponding metal-protein equilibrium stability constant $\left(\mathrm{K}_{\mathrm{i}}\right)$. Among the analytical techniques used to determine these parameters, fluorescence spectroscopic techniques are the most widely used because of their simplicity and high sensitivity $[19,20]$. These techniques are employed to observe fluorescence quenching by titrating protein solutions with metals [18-20]. Fluorescence quenching is the reduction of the fluorescence intensity of a given substance in solution, by the addition of another substance, called the quencher. Quenching may result from a variety of processes [19-21]; it can then be either dynamic, resulting from collision between the fluorophore and quencher, or static, resulting from the formation of a ground-state complex between the fluorophore and quencher, or both dynamic and static. It can reveal the accessibility of quenchers to fluorophore groups of proteins, can help to understand protein binding mechanisms and can provide important information on the nature of the binding phenomenon. Generally fluorescence quenching measurements are performed by the addition of metals into a protein solution in a quartz cell (few $\mathrm{mL}$ ), enabling only a single analysis at once [18-21]. In the present study, a microplate spectrofluorometer [22] was used instead of a classical one. Its main advantage is that in a single assay, 96 samples can be simultaneously analysed. Ensuring that throughout all the experimentations, the stability of the fluorescence parameters (excitation, detection) is constant. The rapidity of the measurements (microplates can be read in a few seconds) associated to the robustness of the technique make it a method of choice for this kind of study. Moreover, in order to amplify the resolution of the $[\mathrm{U}] /[\mathrm{Pi}]$ fluorescence intensity response at low and high protein concentrations, uranium concentrations added to the protein solution were not linear but logarithmic [23]. The metal-protein complexation studies could therefore be realised for a wide range of $[\mathrm{U}] /[\mathrm{Pi}]$ ratios with several replicates.

The objectives of the present work were (1) to demonstrate the suitability of a microplate spectrofluorometer to measure the complexation between uranium and some metalloproteins over a large range of $[\mathrm{U}] /[\mathrm{Pi}]$ ratios, at physiological conditions of $\mathrm{pH}$, (2) to estimate, by fluorescence titration, the stoichiometry of the four U/Pi complexes using existing methods, and (3) using a new approach, to evaluate the complexing capacities and stability constants $\left(\mathrm{L}_{\mathrm{i}}\right.$, $\mathrm{K}_{\mathrm{i}}$ ) of the different complexing sites of each metalloprotein by fitting titration experimental data with the software PROSECE (Programme d'Optimisation et de Spéciation Chimique dans l'Environnement) [23-25].

\section{Experimental}

\section{Reagents}

All solutions were prepared with high-purity de-ionised water (resistivity $\geq 18.2 \mathrm{M} \Omega \mathrm{cm}$ ) obtained from a doubly Milli-Q water purification system (Millipore Synergy 185 and Millipore Helix systems). All reagents were of the highest grade available from Sigma-Aldrich (St. Quentin Fallavier, France) and Calbiochem (VWR International, Fontenay sous Bois, France) and were used without any further purification.

Apo-HTF, molecular weight $76-81 \mathrm{kDa}$, was obtained as a lyophilized powder (purity $\geq 98 \%$, Sigma T4283). HSA, molecular weight $66.5 \mathrm{kDa}(97-99 \%)$, was used as a crystallized and lyophilized powder (Sigma A9511). MT, molecular weight $7 \mathrm{kDa}$ and consisting of two isoforms I and II (Cd 6.7\%, Zn 0.5\%), was defined as essentially salt free (Sigma M7641). Apo-EqSF, molecular weight $460 \mathrm{kDa}$, was obtained as a lyophilized white powder (iron $<0.01 \%$, Calbiochem 178440). Uranium, as uranyl nitrate hexahydrate $\left(\mathrm{UO}_{2}\left(\mathrm{NO}_{3}\right)_{2} \cdot 6 \mathrm{H}_{2} \mathrm{O}\right.$, molecular weight $=$ $502.13 \mathrm{~g} \mathrm{~mol}^{-1}$ ), was $98-102 \%$ (Sigma 94270) and was dissolved in a $1.5 \%$ nitric acid solution $([\mathrm{U}]=9.6 \mathrm{mM})$. HEPES (Sigma 54457, purity $\geq 99.5 \%$ ) was used as a buffer by dissolution of the powder in water.

\section{Preparation of solutions}

HEPES buffer solution $(50 \mathrm{mM})$ was prepared by dissolving the powder in de-ionised water. The $\mathrm{pH}$ was then adjusted to 7.4 with $\mathrm{NaOH}(1 \mathrm{M})$. Proteins solutions were obtained by dissolving an appropriate amount of each protein in the HEPES buffer solution $(50 \mathrm{mM}, \mathrm{pH}=7.4)$. Two uranyl working solutions $(0.1 \mathrm{mM}$ and $1.0 \mathrm{mM})$ were 
prepared daily from the uranyl stock solution $(9.6 \mathrm{mM})$ diluted with de-ionised water. All solutions were kept in the dark at $4{ }^{\circ} \mathrm{C}$.

\section{Instrumentation}

Fluorescence quenching experiments were realised using a microplate spectrofluorometer (SPECTRAmax GEMINIXS, Molecular Device) equipped with a Xenon flash lamp (1 Joule/flash). Data obtained from the quenching of fluorescence experiments were collected with SoftMax Pro software (Molecular Devices). Microplates used for experiments were black walled and clear bottomed quartz 96-wells (cat ${ }^{\circ} 730,009 \mathrm{~B}-\mathrm{QG}$, Hellma, Paris, France). Dimensions were of $14.5 \times 127.0 \times 85.5 \mathrm{~mm}$ and the well volume was $300 \mu \mathrm{L}$.

General procedure of fluorescence quenching experiments

For each protein studied, it was first established if the protein emitted fluorescence, and its optimal excitation and emission wavelength combination was determined $\left(\lambda_{\text {ex }} \cdot /\right.$ $\lambda_{\mathrm{em}}$. combination). Then, for uranium-protein system studies, different amounts $(1-20 \mu \mathrm{L})$ of uranium were added to $280 \mu \mathrm{L}$ of the specific protein solution in the microplate wells. The well volume was then adjusted to $300 \mu \mathrm{L}$ with HEPES (0.05 M, pH=7.4). The additions of uranium, concentrations ranged from 0.65 to $577 \mu \mathrm{M}$ for the U-Apo-HTf, U-HSA and U-MT systems, and from 0.16 to $833 \mu \mathrm{M}$ for the U-Apo-EqSF system were logarithmic additions, i.e. $\Delta(\log [\mathrm{U}])=$ constant. With the aim of not precipitating uranyl ions in the wells, the maximum $\mathrm{UO}_{2}{ }^{2+}$ concentration added did not exceed $833 \mu \mathrm{M}$, even if the fluorescence quenching was not total i.e. the fluorescence intensity of the U-Pi system was higher than those observed for the HEPES solution alone. Logarithmic increases of concentration improved accuracy of the method and allowed us to obtain a better determination of the complexing properties for the smallest concentrations of uranium as well as for the highest ones [25]. All experiments were carried out in triplicate. Final protein concentrations varied depending on the protein studied and its intrinsic fluorescence: Apo-HTf concentrations in the well ranged from 0.5 to $12.5 \mu \mathrm{M}(0.5,1.5,2.5,3.7,5.5$, $7.5,10.0,12.5 \mu \mathrm{M})$, HSA concentrations ranged from 2.5 to $20.5 \mu \mathrm{M}(2.5,4.5,7.5,10.0,13.0,16.0,20.5 \mu \mathrm{M})$, MT concentrations ranged from 55 to $170 \mu \mathrm{M}(55,95,170 \mu \mathrm{M})$ and Apo-EqSF ranged from 0.5 to $8.0 \mu \mathrm{M}(0.5,0.75,1.0$, $1.5,2.0,3.0,4.0,6.0,8.0)$. The $[\mathrm{U}] /[\mathrm{Pi}]$ molar ratios tested therefore ranged from 0.05 to 1150 for the U-Apo-HTf and U-HSA systems, and from 0.02 to 1600 for the UApo-EqSF system. Data were characterized by 210 fluorescence measurements for these three experiments and by 90 fluorescence measurements for the U-MT system with $[\mathrm{U}] /[\mathrm{MT}]$ molar ratios ranging from 0.004 to 6.8 .

Fluorescence measurements were performed at room temperature $\left(22 \pm 1{ }^{\circ} \mathrm{C}\right)$ regulated by the apparatus directly within the microplate spectrofluorometer. An incubation time of $1 \mathrm{~h}$, for each uranium-protein system study, was realised in the spectrofluorometer. Indeed, kinetic complexation studies, carried out in the time interval 0-60 min, showed that the fluorescence signal intensity was stable between a range from 20 to $60 \mathrm{~min}$ after addition of uranium into the protein solution. The microplate was automatically shaken for $5 \mathrm{~s}$ before each reading. In order to verify the accuracy of the method and the stability of the $\mathrm{U} / \mathrm{Pi}$ complex, ten measurements of each sample were realised successively. The mean and standard deviation of all measurements were then calculated and used in the data analyses.

The $\mathrm{pH}$ of the solution in the quartz wells was measured after quenching experiments, with a microelectrode (MI414, Microelectrodes Inc., Bedford, N.H., USA) connected to a conventional $\mathrm{pH}$ meter (Titralab TIM 900, Radiometer Analytical, Lyon, France). Since proteins and particularly Apo-HTf and Apo-EqSF have a very high affinity for ferric and metal ions, the quartz microplates were soaked daily in $0.5 \mathrm{M} \mathrm{HNO}_{3}$ for $1 \mathrm{~h}$ and then rinsed five times with distilled water before use.

Methods of data analysis

\section{Fluorescence quenching mechanisms}

The dynamic or static nature of the fluorescence quenching was investigated for the four U-metalloprotein systems. Graphs were plotted according to the Stern-Volmer equation [20]:

$F_{0} / F=1+k_{q} \tau_{0}[Q]=1+K_{S V}[Q]$

where $F_{0}$ and $F$ are the relative fluorescence intensities of proteins (Apo-HTf, HSA, MT and Apo-EqSF) in the absence and in the presence of uranium respectively; $[Q]$ the quencher concentration $(\mathrm{M})$, here $[\mathrm{Q}]=[\mathrm{U}] ; k_{q}$ the biomolecular quenching rate constant $\left(\mathrm{M}^{-1} \mathrm{~s}^{-1}\right) ; \tau_{0}$ the lifetime of the fluorophore in the absence of uranium (s); and $K_{S V}$ the Stern-Volmer constant $\left(\mathrm{M}^{-1}\right)$.

If the evolution of $F_{0} / F$ plots, according to the concentration of quencher, is linear for the whole range of quencher concentrations, fluorescence quenching can be attributed either to being purely dynamic, or purely static. The latter mechanism being due to the formation of a ground-state non-fluorescent complex. In contrast, if the ratio $F_{0} / F$ is not linear and shows an upward curve at higher quencher concentrations, the fluorescence quenching mechanism can 
be attributed to the presence of simultaneous dynamic and static quenching. In the latter situation, from the bimolecular quenching rate constant value $k_{q}$, determined in the linear range of the $F_{0} / F$ ratio, the initial fluorescence quenching mechanism can be determined. Typically, if $k_{q}$ is much higher than $10^{10} \mathrm{M}^{-1} \mathrm{~s}^{-1}$, i.e., the upper value possible for diffusion-limited quenching in most solutions at room temperature, the fluorescence quenching mechanism is initially a static one, whereas with the lower $k_{q}$ values it is initially a dynamic quenching $[20,21]$.

\section{Fitting model: PROSECE software}

The experimental fluorescence data obtained were also analysed with the PROSECE software, which allows the determination of complexing properties using a discrete model of binding sites distribution. This software has previously been successfully applied in the determination of binding parameters between metal and dissolved natural organic matter [24], as well as, between metal and synthetic ligands [25]. The fitting establishes the optimal number of binding sites with corresponding stability constant $\left(\mathrm{K}_{\mathrm{i}}\right)$ and site density $\left(\mathrm{L}_{\mathrm{i}}\right)$ values. To give the best binding parameters, the quantum yield $\left(\mathrm{Q}_{\mathrm{Li}}\right)$ of the non-complexed ligand form $\left(\mathrm{L}_{\mathrm{i}}\right)$ was optimized assuming that the complexed form $\left(\mathrm{U}-\mathrm{L}_{\mathrm{i}}\right)$ is non-fluorescent (i.e. $\mathrm{Q}_{\mathrm{U}-\mathrm{Li}}$ equals to 0 ) and that the fluorescence intensity measured throughout the titration tends towards 0 . The PROSECE algorithm was used to fit the fluorescence data of our experiments. For each U(VI)-protein complex, two discrete models of binding site distribution were tested by PROSECE to fit the quenching of fluorescence at different titration points, i.e., a first fitting with one specific complexation site and a second with two specific complexation sites. In both cases, the $\mathrm{U}-\mathrm{L}_{\mathrm{i}}$ considered stoichiometry was a 1:1 one. PROCESE fitting with three complexation sites were also carried out. However, as results obtained were not better than those with two complexation sites, this model was not considered in the rest of the study.

\section{Results and discussion}

Spectral characteristics of Apo-HTf, HSA, MT and Apo-EqSF proteins

As mentioned in the General procedure section, the first experiments were realised to determine the optimal $\lambda_{\mathrm{ex}} / \lambda_{\mathrm{em}}$. combination for Apo-HTf, HSA, MT and Apo-EqSF. An optimal $\lambda_{\mathrm{ex}} / \lambda_{\mathrm{em}}$. combination could be determined when the signal-to-noise ratio at both $\lambda_{\text {ex }}$ and $\lambda_{\text {em. }}$. wavelengths is the highest. Excitation and emission wavelengths of proteins were also recorded. Values obtained for the optimum $\lambda_{\text {ex }} . \lambda_{\text {em. }}$ combinations were of $279 / 327 \mathrm{~nm}, 279 /$ $330 \mathrm{~nm}, 282 / 346 \mathrm{~nm}$ and 279/325 nm for Apo-HTf, HSA, MT and Apo-EqSF respectively. Theses results indicated that excitation wavelength values were about the same for the four metalloproteins $(\sim 280 \mathrm{~nm})$. For the emission wavelength values, Apo-HTf, HSA and Apo-EqSF values were close $(327 \mathrm{~nm}, 330 \mathrm{~nm}$ and $325 \mathrm{~nm}$ respectively), while the value obtained for MT was higher $(346 \mathrm{~nm})$. According to the literature data $[20,21,26]$, results obtained for Apo-HTf, HSA and Apo-EqSF $\left(\lambda_{\mathrm{ex}} / \lambda_{\mathrm{em}} \approx\right.$ $280 / 330 \mathrm{~nm}$ ) were due to the presence of tryptophan (an aromatic amino acid). For MT, since aromatic amino acids were absent from this protein, fluorescence properties were probably due to the polypeptide chains [27].

The fluorescence intensity varied linearly with the protein concentration (mean correlation coefficients $\left(\mathrm{r}^{2}\right)$ higher than 0.99 ) in the range of $0.5-12.5 \mu \mathrm{M}$ for Apo-HTf, 2.5-20.5 $\mu \mathrm{M}$ for HSA, 55-170 $\mu \mathrm{M}$ for MT and $0.5-8.0 \mu \mathrm{M}$ for Apo-EqSF (data not shown). The proteins were therefore neither affected nor denatured in the concentration range studied. This was of paramount importance for fitting the data obtained during the quenching experiments and interpretation.

Fluorescence quenching of Apo-HTf, HSA, MT and Apo-EqSF by uranium

\section{Quenching spectra of the metalloproteins}

Fluorescence titrations on Apo-HTf, HSA, MT and ApoEqSF were achieved by addition of a solution of $\mathrm{UO}_{2}{ }^{2+}$ in $0.1 \mathrm{M}$ HEPES at $\mathrm{pH}$ 7.4. An example of spectra obtained for one concentration of each protein is presented in Fig. 1.

As shown in Fig. 1, the fluorescence intensities of the four metalloproteins decrease concomitantly with increasing $\mathrm{UO}_{2}{ }^{2+}$ concentration. Furthermore, the spectra show that there are no significant $\lambda_{\mathrm{em}}$. shifts with the addition of uranyl ions for any of the four proteins. These data indicated that $\mathrm{UO}_{2}{ }^{2+}$ could interact with Apo-HTf, HSA, MT and Apo-EqSF and quenched their fluorescence without changing their microenvironment properties.

\section{Stoichiometry of the U/Pi complexes}

The evolution of the fluorescence intensity versus the molar ratio $[\mathrm{U}] /[\mathrm{Pi}]$ was studied in order to determine the stoichiometry of the binding reactions between metalloproteins and uranium. As an example, Fig. 2 shows typical titration curves of three different concentrations of Apo$\operatorname{HTf}(3.75 \mu \mathrm{M}, 5.50 \mu \mathrm{M}$ and $7.50 \mu \mathrm{M})$ quenched by $\mathrm{UO}_{2}{ }^{2+}$. This so called 'graphic method' is commonly used method in the literature for the determination of the stoichiometry of a reaction in quenching studies $[8,18,28]$. 

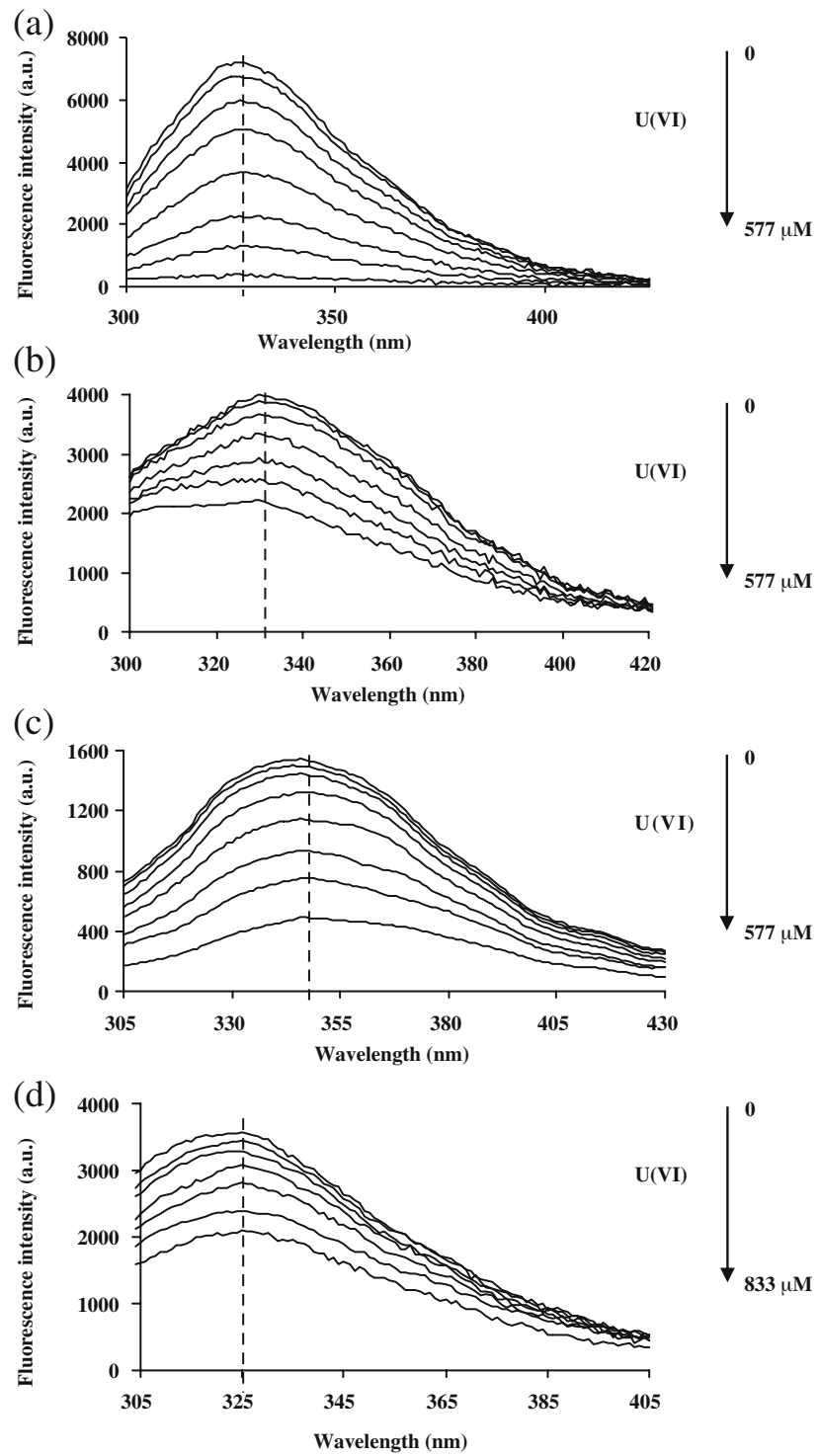

Fig. 1 Fluorescence spectra of $10.0 \mu \mathrm{M}$ Apo-HTf (a), $7.5 \mu \mathrm{M}$ HSA (b), 55.0 $\mu \mathrm{M}$ MT (c), and 4.0 $\mu \mathrm{M}$ Apo-EqSF (d), in 0.05 M HEPES $(\mathrm{pH}=7.4)$ and in the presence of increasing uranium at ambient conditions $\left(\lambda_{\mathrm{ex} .}=279 \mathrm{~nm}\right.$ for (a), (b), (c), and $282 \mathrm{~nm}$ for (d), excitation and emission slits are $2 \mathrm{~nm}$ )

As described above, the addition of uranium concentrations to different solutions of Apo-HTf led to a decrease of the protein fluorescence intensity, showing the quenching of Apo-HTf fluorescence by U(VI). Analysis of the curves obtained in Fig. 2 indicates that for all three different Apo-HTf concentrations, a sharp break occurs at a molar ratio $[\mathrm{U}] /[\mathrm{Pi}]$ of 2 . This result was in agreement with published literature using different techniques to study UApoHTf complexation, such as spectroscopic UV-visible [8] or time resolved laser-induced fluorescence [18]. According to these studies, the stoichiometry of the complexation between uranium(VI) and Apo-HTf was a 2:1 stoichiometry and the reaction of complexation could be expressed by the equation given in Table 1 .

The consistency of our data with previous published findings, validated both the use of a microplate spectrofluorometer and the logarithmic concentration increase of $U$ (VI) for the determination of the complex stoichiometry between $\mathrm{UO}_{2}{ }^{2+}$ and proteins. Results obtained for the stoichiometry determination of each binding reaction, namely between U(VI) and respectively, Apo-HTf, HSA, MT and Apo-EqSF are summarized in Table 1.

As shown in Table 1, 'graphic method' stoichiometries of the reactions between uranium and the four proteins cited are very different: stoichiometry of Apo-EqSF with uranium being much higher (U:Apo-EqSF=525/1) than those obtained for the reactions between uranium and the three other proteins (ratio in a range from 3:2 to 5:1). These results are in agreement with those obtained in the earlier literature for Apo-HTf [18, 29] and Apo-EqSF [15]. Indeed, according to Hainfeld (1992), $\approx 400$ uranium atoms can be loaded in the central cavity of one Apo-EqSF when the protein is preincubated in $\mathrm{pH} 9$ buffer and $\approx 800$ uranium atoms when Apo-EqSF is preincubated in $\mathrm{pH} 4$ buffer [15].

However, even though the 'graphic method' gives some satisfactory information about the complexation between uranium and proteins, it has its limits. The method is not rigorous enough and is dependant on a visual interpretation of the titration curve: the reaction stoichiometry is determined by curve inflections which are obtained by the intersection of tangents deduced from the titration curve extremities. The accuracy of the tangent intersection is therefore dependent on the number of data points defining the high and low uranium concentrations. Furthermore, with 'graphic method', only one protein complexation site could be taken into account. The existence of several complexation sites such as the presence of strong complexation sites at low concentrations could be missed or misinterpreted with this method. In addition, in our case we were not able to deduce anything about the nature of either the quenching mechanism which occurred or the complexes formed.

\section{Binding properties of the U/Pi complexes}

- Fluorescence quenching mechanisms

In order to determine the quenching mechanisms occurring between the four metalloproteins cited and uranium, the fluorescence titration data were investigated using the Stern-Volmer plots. Figure 3 shows the results obtained for the $F_{0} / F$ ratio evolution against $\mathrm{U}(\mathrm{VI})$ concentration for Apo-HTf, HSA, MT and Apo-EqSF (at concentrations of $7.5 \mu \mathrm{M}, 10.0 \mu \mathrm{M}, 95.0 \mu \mathrm{M}$ and $2.0 \mu \mathrm{M}$, respectively).

It is interesting to note that Fig. 3 highlights a contrast in the quenching behaviour of the four proteins. While $F_{0} / F$ 
Fig. 2 Apo-HTf fluorescence intensity as a function of $[\mathrm{U}] /[$ Apo-HTf] molar ratio. Conditions: $\lambda_{\mathrm{ex} .}=279 \mathrm{~nm}-\lambda_{\mathrm{em} .}=$ $327 \mathrm{~nm}-\mathrm{pH}=7.4-[$ HEPES] $=$ $50 \mathrm{mM}-\mathrm{T}=22 \pm 1^{\circ} \mathrm{C}-$-Incubation time: $1 \mathrm{~h}$

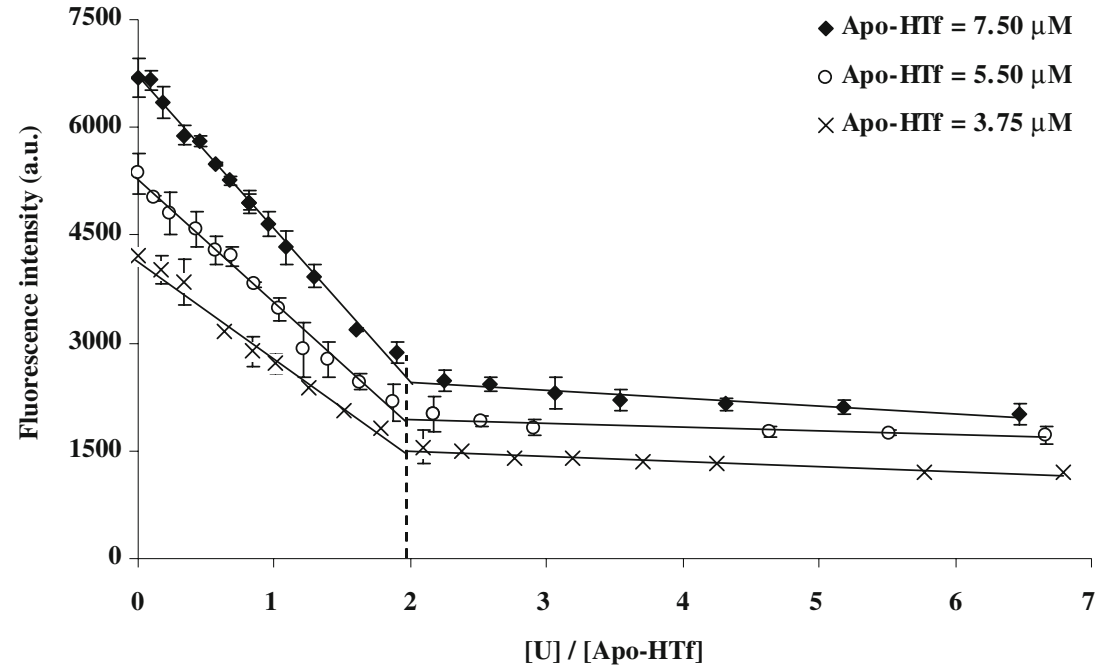

varies linearly for Apo-EqSF with $\mathrm{UO}_{2}{ }^{2+}$ concentrations, an upward curve is clearly observed for the three other proteins. The Stern-Volmer $F_{0} / F$ plots of Apo-HTf, HSA and MT progressively deviated from linearity towards the $y$-axis at higher uranium concentrations. This result indicates that the quenching mechanism occurring between Apo-EqSF and $\mathrm{UO}_{2}{ }^{2+}$ is different from those occurring between Apo-HTf, HSA, MT and $\mathrm{UO}_{2}{ }^{2+}$. For these three last metalloproteins, quenching process can not be explained by a purely dynamic or a purely static process, but must be a combination of the two mechanisms.

As shown in the insert of Fig. 3, for low uranium additions, Stern-Volmer graphics are linear for Apo-HTf, HSA and MT. Based on these experimental data, biomolecular quenching rate constants $k_{q}$ and Stern-Volmer constants $K_{S V}$ are deduced from Eq. 1 in this linear range of $F_{0} / F$ ratio. $k_{q}$ data were found to be in an order of magnitude of $10^{12} \mathrm{M}^{-1} \mathrm{~s}^{-1}$ for MT $(95.0 \mu \mathrm{M})$ and $10^{13} \mathrm{M}^{-1} \mathrm{~s}^{-1}$ for ApoHTf $(7.5 \mu \mathrm{M})$ and HSA $(10.0 \mu \mathrm{M})$ respectively. These values were $10^{2}-10^{3}$ fold higher than the upper value possible for diffusion-limited quenching $\left(\approx 10^{10} \mathrm{M}^{-1} \mathrm{~s}^{-1}\right)[20,21]$. This suggested that the fluorescence quenching was not initiated by dynamic quenching but by static one, starting with the formation of a complex between uranyl ions and the three metalloproteins. For Apo-EqSF, the biomolecular quenching rate constant obtained $\left(\approx 5 \times 10^{11} \mathrm{M}^{-1} \mathrm{~s}^{-1}\right)$ indicated that the fluorescence quenching may be considered as purely static for all uranium concentrations tested.

If the biomolecular quenching rate $k_{q}$ could give information on the nature of quenching occurred, the Stern-Volmer constant $K_{S V}$ could be assimilated to a binding constant. Thus, $\log K_{S V}$ values were calculated to be 5.3, 4.1, 3.9 and 3.5 for Apo-HTf, HSA, MT and ApoEqSF respectively. These values seemed to show that binding of uranium is higher with Apo-HTf $>$ HSA $>$ MT $>$
Apo-EqSF. However, using this Stern-Volmer approach only the linear range of $F_{0} / F$ ratio can be used thus excluding the high uranium concentration range values for the first three cited metalloproteins. In addition the number of binding sites and their density could not be obtained.

- Binding constants and binding sites determination with PROSECE software

Determination of the number of protein binding sites and their affinity for uranyl ions was accomplished using PROSECE software. All the experimental data were fitted simultaneously with this software which is based on a discrete distribution of binding sites. For the four proteins studied, we were confident that the U-Pi complex formed was a non-fluorescence complex (quantum yield, $\mathrm{Q}_{\mathrm{U}-\mathrm{Pi}_{\mathrm{i}}}=0$ ). A distribution of two binding sites $\left(\mathrm{L}_{1}\right.$ and $\left.\mathrm{L}_{2}\right)$ was optimal to simulate all the titrations obtained between proteins and uranium. Each protein complexing site was defined by a binding site density (mole of U(VI) complexed per mole of $\mathrm{Pi}$ ) and a stability constant (log $\mathrm{K}_{\mathrm{i}}$ ) towards uranyl ions, i.e., four unknown parameters for each protein. The values of these four parameters were optimized using PROSECE, by fitting experimental fluorescence data obtained for all the protein concentrations. The parameters values optimized for each protein were averaged and summarized in Table 1. Results of fitting by the proposed model of the experiments carried out on Apo-HTf are shown in Fig. 4.

PROSECE model, including two specific complexation sites, correlated closely with the experimental data obtained from the fluorescence quenching study of Apo-HTf by uranium (Fig. 4). Because the whole uranium concentration range was used to determine binding parameters with PROSECE, results obtained permitted the global identification of the complexation reactions between $\mathrm{U}$ and Apo- 
HTf. The same conclusions were obtained for the three other proteins and their associated U-Pi complexes (not presented here). According to the binding constant values obtained and summarized in Table 1, for each protein studied we established a 'strong' $\left(\mathrm{L}_{1}\right)$ and a 'weak' $\left(\mathrm{L}_{2}\right)$ binding site. Results in Table 1 also show that $\mathrm{L}_{1}$, the 'strong' binding sites, are sites with the lower number of $U$ (VI) atoms complexed per mole of protein, and $\mathrm{L}_{2}$, the 'weak' binding sites, are sites with the higher number of $U$ (VI) atoms complexed per mole of protein. PROSECE results clearly showed that MT is the metalloprotein with the lowest binding site density $(5.3 \pm 0.3$ moles of $\mathrm{U}(\mathrm{VI})$ per mole of MT by addition of site 1 and site 2 densities), whereas Apo-EqSF is those with the highest one (550.8 \pm 26.9 moles of U(VI) per mole of Apo-EqSF by addition of site 1 and site 2 densities). However, this last one has the lowest $\mathrm{L}_{1}$ binding constant $\left(\log \mathrm{K}_{1}=5.3 \pm 0.6\right)$, whereas Apo-HTf has the highest one ( $\left.\log \mathrm{K}_{1}=7.7 \pm 0.6\right)$. Thus, combinations of binding constants and binding site densities reported in Table 1 suggest that uranium would be bound preferentially with Apo-HTf rather than with the three other metalloproteins if concentrations of these latter are similar.

Regarding the binding site density values obtained with PROSECE, it appeared that for the U-Apo-HTf complex, the first complexation site $\mathrm{L}_{1}$ was the site identified by the 'graphic method' (see Table 1 and Fig. 2). Thus, PROSECE modelling allowed us to confirm this first site but also to identify a second binding site characterized by both a 'weaker' complexation constant $\left(\log \mathrm{K}_{2}=4.6 \pm 0.4\right)$ and a much higher U:Apo-HTf stoichiometry (26.6:1). The existence of this second site was not revealed by the 'graphic method' (see Fig. 2). In the case of the U-ApoEqSF complex, the binding site density identified by the 'graphic method' was not the 'stronger' site $\left(\mathrm{L}_{1}\right)$, but the 'weaker' one $\left(\mathrm{L}_{2}\right)$. The density site values obtained with the two methods were close: 504.0 \pm 21.4 (PROSECE) and 525.0 ('graphic method') moles of $U$ per mole of Apo-EqSF (Table 1). Concerning the U-HSA and U-MT complexes, stoichiometries determined by the 'graphic method' (U:HSA=5:1 and U:MT=3/2:1) were in the range of the binding site density determined by PROSECE: $2.3 \pm$ 0.4 and $7.6 \pm 1.2$ moles of U(VI) per mole of HSA, and $0.1 \pm 0.1$ and $5.2 \pm 0.2$ moles of U(VI) per mole of MT, respectively for the $\mathrm{L}_{1}$ and $\mathrm{L}_{2}$ sites. Thus, results obtained for the four U-Pi interactions using PROSECE fitting highlighted the limitations of the 'graphic method' with which only one binding site would have been identified for the four U-Pi complexation reactions studied. This binding site identified by the 'graphic method' was shown to be either one of the real binding site also identified by PROSECE (e.g., Apo-HTf and Apo-EqSF), or an 'artificial' site for which the site density was equal to a combination 
Fig. 3 Plots of Apo-HTf, HSA, MT and Apo-EqSF titrated with $\mathrm{UO}_{2}{ }^{2+}$. Conditions: $[$ Apo-HTf $]=7.5 \mu \mathrm{M}-[\mathrm{HSA}]=$ $10.0 \mu \mathrm{M}-[\mathrm{MT}]=95.0 \mu \mathrm{M}-$ $[\mathrm{Apo}-\mathrm{EqSF}]=2.0 \mu \mathrm{M}-\mathrm{pH}=$ 7.4-[HEPES] $=50 \mathrm{mM}-\mathrm{T}=22 \pm$

$1{ }^{\circ} \mathrm{C}$-Incubation time: $1 \mathrm{~h}$

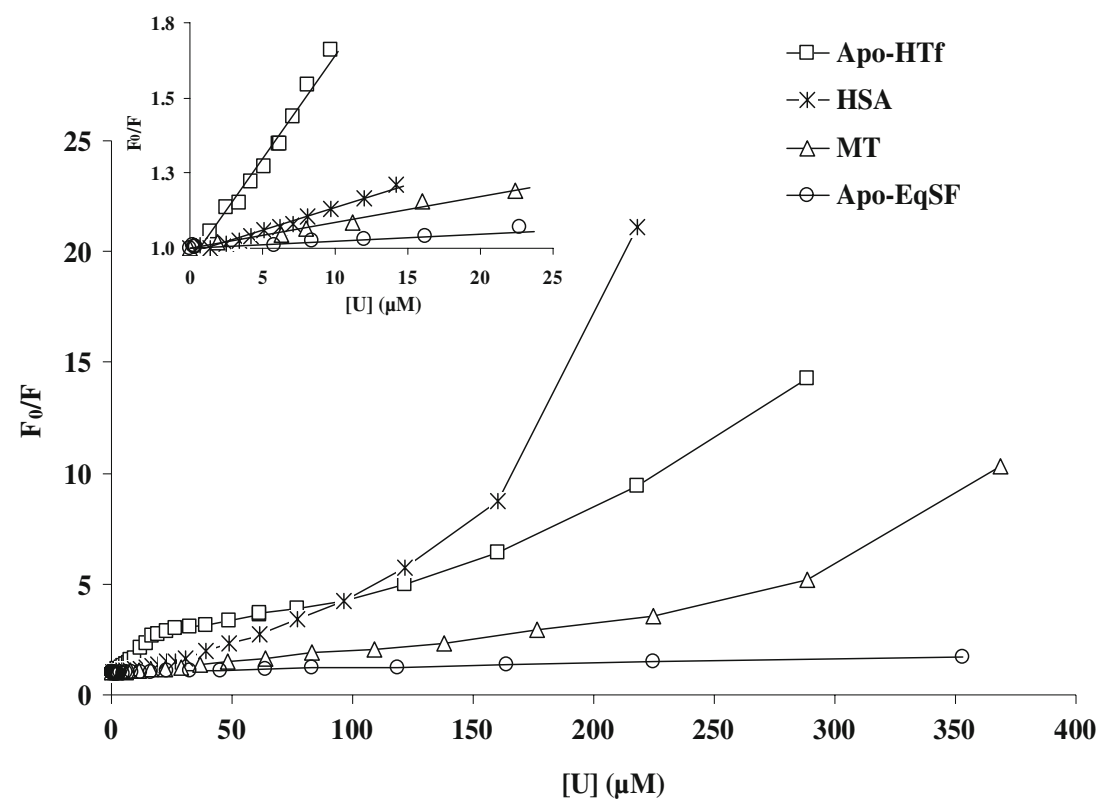

of the density values of the two sites obtained by PROSECE (e.g., HSA and MT).

Regarding the binding constant values obtained, it clearly appeared that binding constants $\mathrm{K}_{2}$, obtained for the 'weaker' site $\mathrm{L}_{2}$ identified by PROSECE (Table 1), were higher for the U-HSA, U-MT and U-Apo-EqSF complexes than binding constants $K_{s v}$ obtained with SternVolmer regression curves. Such differences between the two methods could be explained by the fact that only one fluorescence quenching mechanism (dynamic or static) could be determined using the Stern-Volmer regression curves. With PROSECE fitting, the entire uranium concentration range tested has been used and therefore the two fluorescence quenching mechanisms could be determined. For the Apo-EqSF complex, the binding constant obtained using Stern-Volmer regression $(\log \mathrm{K}=$ 3.5) was about the same as those obtained for the $L_{2}$ site with PROSECE modelling ( $\log \mathrm{K}=3.9 \pm 0.4$ ). However, on the contrary with others, U-Apo-EqSF Stern-Volmer binding constant was obtained by taking into account the full uranium concentration range (fluorescence quenching mechanism due to a purely static quenching). As the 'graphic method' enabled us to determine the second $\mathrm{L}_{2}$ binding site identified by PROSECE (see paragraph above), we can conclude that the combination of 'graphic method' and the Stern-Volmer regression curves give satisfactory results only when a pure quenching mechanism occurred (static or dynamic).

The binding parameter values obtained using PROSECE fitting of these metalloproteins were also compared to reported values with this actinide, or other divalent cations, published in the literature. Concerning Apo-HTf some authors have already reported on its complexation by uranium [3, 16-18]. The data presented here showed that the binding parameters obtained for the first complexation $\mathrm{L}_{1}$ site $\left(\log \mathrm{K}_{1}=7.7 \pm 0.6\right.$ with $1.9 \pm 0.1$ mole of $\mathrm{U}$ complexed per Apo-HTf) were close to those obtained by Scapolan and co-workers [18], i.e. 2.0 moles of U(VI) complexed per mole of Apo-HTf and $\log \mathrm{K}=16$. The only one difference that is the factor of two between both complexation constants is explained because the binding constant obtained by Scapolan and co-workers, was determined under the assumption that the U-Apo-HTf complex formed was a bidentate complex [18]; whereas, in our study, PROSECE was defined as fitting a mono-

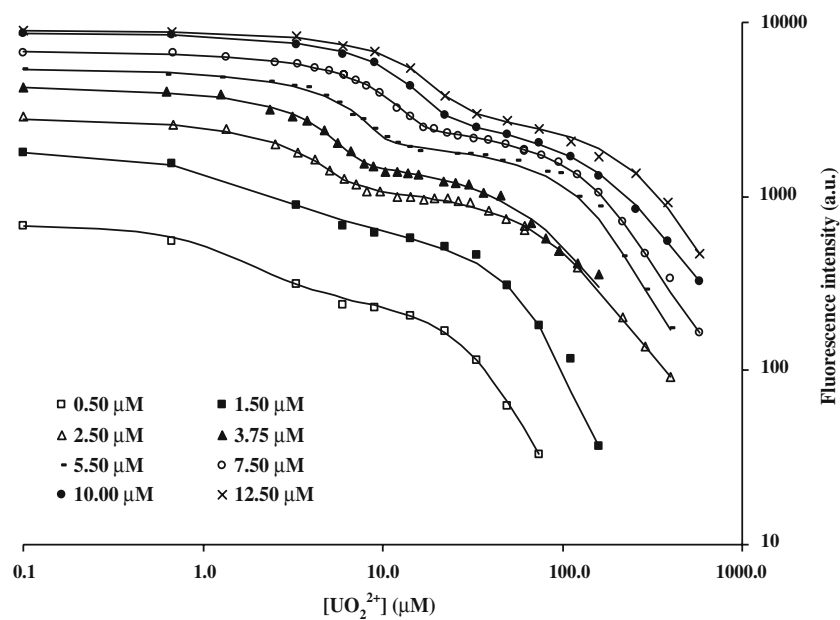

Fig. 4 Experimental fluorescence intensities acquired by the uranium logarithmic addition to the eight different Apo-HTf solutions at $\mathrm{pH} 7.4$ (open and closed geometric forms) and PROSECE corresponding fitting (solid lines) with models using two specific complexation sites. Fluorescence intensities and uranium concentrations were represented in logarithmic scale 
dentate complex with U-Pi stoichiometries of 1:1. At last, the two binding constant values obtained with PROSECE fitting were in agreement with values obtained for others actinides (americium(III) and curium(III)) and lanthanides (neodymium(III), samarium(III) and gadolinium(III)) reported to complex with Apo-HTf [30, 31].

Concerning the U-Apo-EqSF complex, values obtained using PROSECE fitting showed that at physiological $\mathrm{pH}$, 550 uranium atoms could be complexed with the metalloprotein (Table 1) which was in agreement with the results obtained by Hainfeld [15]. Comparisons with binding data obtained for ferritin with some other cations $\left(\mathrm{Zn}^{2+}, \mathrm{Cd}^{2+}\right.$, $\left.\mathrm{Cu}^{2+}, \mathrm{Mn}^{2+}, \mathrm{Tb}^{2+}\right)$ showed similar results both in the number of binding site and in the values of binding constant [32]. Concerning the U-HSA complex, comparison of our results with published data of some other cations likely to bind with the metalloprotein $\left(\mathrm{Cu}^{2+}, \mathrm{Ni}^{2+}\right.$, $\left.\mathrm{Co}^{2+}, \mathrm{Cd}^{2+}, \mathrm{Zn}^{2+}\right)$ also indicated that the binding constant values were in about the same order of magnitude $[9,10]$. Besides, as for our result with uranium, between one and three affinity binding sites were generally described for the differerent cations complexed with HSA [10]. Concerning MT, results obtained for its complexation with $\mathrm{UO}_{2}{ }^{2+}$ were different from those obtained with other cations. Indeed, according to the literature [33], binding constants of $\mathrm{Zn}^{2+}, \mathrm{Cd}^{2+}$ and $\mathrm{Cu}^{2+}$ with MT were between 5 and 10 orders of magnitude higher than those obtained in our study for the U-MT complex. Thus, in a biological media, MT would bind preferentially cations such as $\mathrm{Zn}^{2+}$, $\mathrm{Cd}^{2+}$ and $\mathrm{Cu}^{2+}$ rather than $\mathrm{UO}_{2}{ }^{2+}$, which was not the case for the three other metalloproteins studied.

\section{Conclusion}

In this paper, the interactions of four metalloproteins (ApoHTf, HSA, MT and Apo-EqSF) with uranium were studied by fluorescence quenching measurements. The use of a microplate spectrofluorometer in order to determine the uranium complexing properties had never previously been realised. This novel system enabled us to fully characterize the U-Apo-HTf, U-HSA, U-MT and U-Apo-EqSF complexing properties over a wide range of $[\mathrm{U}] /[\mathrm{Pi}]$ ratios and at physiological $\mathrm{pH}$ conditions (7.4).

As the classical methods ('graphic method' and SternVolmer approach) for the determination of both complex stoichiometries and fluorescence quenching mechanisms had some limitations (particularly when two binding sites were present) experimental data were fitting using PROSECE software. This software had never been used before for the determination of binding and complexing parameters between metal ions and proteins. Our results obtained on the metalloprotein binding parameters showed two classes of complexing sites $\left(\mathrm{L}_{1}\right.$ and $\left.\mathrm{L}_{2}\right)$. Each site was defined by a binding site density and a binding constant. These two complexing sites can be classified as: a 'strong' binding site $\left(\mathrm{L}_{1}\right)$ with a high equilibrium stability constant and a low binding site density; and a 'weak' binding site $\left(\mathrm{L}_{2}\right)$ characterized by a low equilibrium stability constant density and a high binding site. Concerning the U-ApoHTf and U-Apo-EqSF complexes, the binding site densities and stability constants obtained have improved the understanding of the complexing properties of these proteins with uranium. The binding constants and site density values relative to the U-HSA and U-MT complexes have been elucidated. It corresponded to the first estimation ever done of these binding parameter values.

The method using a microplate spectrofluorometer, now validated on metalloproteins, will be of importance in establishing the complexation parameters of uranium with other functional proteins not a priori dedicated to metal chelation but affected by uranium exposition. This will then provide new thermodynamic data on uranium-protein interactions with a future perspective of their inclusion in existing thermodynamic models. Indeed, these latter could permit, in a long term, a better understanding of uranium entry, depuration, storage and distribution in contaminated organisms. However, when using thermodynamic data with the objective of predicting biological distribution, some cautions must be used. Indeed, it is worth noting that the concentration of uranium, as a pollutant in organisms, might always be lower than those of essential metals such as zinc and copper. Competition between ions in living organisms must be considered in order to determine the real complexation of metalloproteins with uranyl ions.

Acknowledgements This work is a part of the ENVIRHOM research program supported by the Institute for Radioprotection and Nuclear Safety. The authors would like to thank Thomas Hinton and Katherine Harper for the rereading of the manuscript and English corrections.

\section{References}

1. Colle C, Garnier-Laplace J, Roussel-Debet S, Adam C, Baudin JP (2001) In: Métivier H (ed) L'uranium, de l'environnement à l'homme, EDP Sci., Les Ullis, pp. 187-211

2. Van Horn JD, Huang H (2006) Uranium(VI) bio-coordination chemistry from biochemical, solution and protein structural data. Coord Chem Rev 250(7-8):765-775

3. Vidaud C, Dedieu A, Basset C, Plantevin S, Dany I, Pible O, Quéméneur E (2005) Screening of human serum proteins for uranium binding. Chem Res Toxicol 18(6):946-953

4. Taylor DM (1998) The bioinorganic chemistry of actinides in blood. J Alloy Compd 271-273:6-10

5. Ansoborlo E, Prat O, Moisy P, Den Auwer C, Guilbaud P, Carrière M, Gouget B, Duffield J, Doizy D, Vercouter T, Moulin C, Moulin V (2006) Actinide speciation in relation to biological processes. Biochimie 88(11):1605-1618 
6. Sun H, Li H, Sadler PJ (1999) Transferrin as a metal ion mediator. Chem Rev 99(9):2817-2842

7. Harris WR (1998) In: Clarke MJ, Allan CB (eds) Less common metals in proteins and nucleic acid probes, vol 92. Springer, New York, pp 121-162

8. Togashi DM, Ryder AG (2008) A fluorescence analysis of ANS bound to bovine serum albumin: binding properties revisited by using energy transfer. J Fluoresc 18(2):519-526

9. Shen XC, Liang H, Guo JH, Song C, He XW, Yuan YZ (2003) Studies on the interaction between $\mathrm{Ag}^{+}$and serum albumin. $\mathrm{J}$ Inorg Biochem 95(2-3):124-130

10. Sanna D, Garribba E, Micera G (2009) Interaction of $\mathrm{VO}^{2+}$ ion with human serum transferrin and albumin. J Inorg Biochem. doi:10.1016/j.jinorgbio.2009.01.002

11. Stillman MJ (1995) Metallothioneins. Coord Chem Rev 144:461-511

12. Vaher M, Romero-Isart N, Vaš k M, Palumaa P (2001) Reactivity of $\mathrm{Cd} 7$ - metallothionein with $\mathrm{Cu}$ (II) ions: evidence for a cooperative formation of $\mathrm{Cd} 3, \mathrm{Cu}(\mathrm{I}) 5-$ metallothionein. J Inorg Biochem 83(1):1-6

13. Chan J, Huang Z, Merrifield ME, Salgado MT, Stillman MJ (2002) Studies of metal binding reactions in metallothioneins by spectroscopic, molecular biology, and molecular modeling techniques. Coord Chem Rev 233-234:319-339

14. Theil EC (1990) The ferritin family of iron storage proteins. Adv Enzymol Relat Areas Mol Biol 63:421-449

15. Hainfeld JF (1992) Uranium-loaded apoferritin with antibodies attached: molecular design for uranium neutron-capture therapy. Proc Natl Acad Sci USA 89(22):11064-11068

16. Vidaud C, Gourion-Arsiquaud S, Rollin-Genetet F, Torne-Celler C, Plantevin S, Pible O, Berthomieux C, Quéméneur E (2007) Structural consequences of binding of $\mathrm{UO}_{2}^{(2+)}$ to apotransferrin: can this protein account for entry of uranium into human cells? Biochemistry 46:2215-2226

17. Paquet F, Frelon S, Cote G, Madic C (2003) The contribution of chemical speciation to internal dosimetry. Radiat Prot Dosim 105 (1-4):179-184

18. Scapolan S, Ansoborlo E, Moulin C, Madic C (1998) Uranium (VI)-transferrin system studied by time-resolved laser-induced fluorescence. Radiat Prot Dosim 79(1-4):505-508

19. Pandey S, Ali M, Bishnoi A, Azam A, Pandey S, Chawla HM (2008) Quenching of pyrene fluorescence by calix[4]arene and calix[4]resorcinarenes. J Fluoresc 18(2):533-539

20. Lakowicz JR (2006) Principles of fluorescence spectroscopy, 3rd edn. Springer, Berlin
21. Valeur B (2007) Molecular fluorescence: principles and applications 4th reprint. Weinheim, Wiley- $\mathrm{VCH}$

22. García-Sánchez F, Navas Díaz A, González Díaz AF, Eremin SA (1999) Quantification of 2, 4, 5-trichlorophenoxyacetic acid by fluorescence enzyme-linked immunosorbent assay with secondary antibody. Anal Chim Acta 378(1-3):219-224

23. Garnier C, Pižeta I, Mounier S, Benaim JY, Branica M (2004) Influence of the type of titration and of data treatment methods on metal complexing parameters determination of single- and multiligand systems measured by stripping voltametry. Anal Chim Acta 505(2):263-275

24. Louis Y, Garnier C, Lenoble V, Omanović D, Mounier S, Pižeta I (2009) Characterisation and modelling of marine dissolved organic matter interactions with major and trace cations. Mar Environ Res 67(2):100-107

25. Lenoble V, Garnier C, Masion A, Ziarelli F, Garnier JM (2008) Combination of $13 \mathrm{C} / 113 \mathrm{Cd} \mathrm{NMR}$, potentiometry, and voltammetry in characterizing the interactions between $\mathrm{Cd}$ and two models of the main components of soil organic matter. Anal Bioanal Chem 390(2):749-757

26. Wei Y-L, Li J-Q, Dong C, Shuang S-M, Liu D-S, Huie CW (2006) Investigation of the association behaviors between biliverdin and bovine serum albumin by fluorescence spectroscopy. Talanta 70 (2):377-382

27. Tie J-K, Li L-Y, B-G Ru (1996) Fluorimetric study of the isoform difference of mammalian metallothionein. J Biochem Biophys Methods 33(3):245-233

28. Gök E, Öztürk C, Akbay N (2008) Interaction of thyroxine with seven hydroxycoumarin: a fluorescence quenching study. J Fluoresc 18(5):781-785

29. Harris WR (1992) Equilibrium model for speciation of aluminium in serum. Clin Chem 38(9):1809-1818

30. Harris WR (1986) Binding constants for neodymium(III) with human serum transferrin. Inorg Chem 25(12):2041-2045

31. Zak O, Aisen P (1988) Spectroscopic and thermodynamic studies on the binding of gadolinium(III) to human serum transferrin. Biochemistry 27(3):1075-1080

32. Pead S, Durrant E, Webb B, Larsen C, Heaton D, Johnson J, Watt GD (1995) Metal ion binding to apo, holo, and reconstituted horse spleen ferritin. J Inorg Biochem 59(11):15-27

33. Petering DH, Fowler BA (1986) Discussion summary. Roles of metallothionein and related proteins in metal metabolism and toxicity: problems and perspectives. Environ Health Perspect 65 (3):217-224 